\title{
TUTURAN MELARANG DALAM FILM SPIRITED AWAY
}

\author{
Oktaviani Saputri \\ oktavianisaputri29@gmail.com \\ Universitas Dian Nuswantoro
}

\begin{abstract}
The Purpose of this study is to describe the use of directive speech acts of prohibition in the Spirited Away movie which are based on the pattern of prohibitions in Japanese. It also aims to find out the factors that influence the prohibition of speech based on the context of the conversation and categorized them into direct or indirect speech. The data of this research were taken from the utterance of the characters containing the directive speech acts of prohibition. The use of prohibition directive speech acts is analyzed based on the prohibition pattern in Japanese in accordance with the theory of Namatame. This type of research uses the qualitative descriptive research method with a pragmatic approach. From the results of data analysis it was found that the use of illocutionary speech forms directly prohibits, which are: the patterns of $\sim$ V ru na, $\sim$ te wa ikenai, $\sim$ naide, $\sim$ dame, and $~$ janai. Ilocutionary forms are directly used by people who have strong authority over their partners. With his authority the speaker does not need to use indirect speech which usually emphasizes modesty.
\end{abstract}

Keywords : Context, Directive Speech Acts, Namatame, Prohibition, Speech Acts.

Peristiwa tutur adalah berlangsungnya interaksi linguistik dalam satu bentuk ujaran atau lebih yang melibatkan dua pihak yaitu penutur dan lawan tutur dengan satu pokok tuturan, tempat, dan situasi tertentu yang membentuk sebuah komunikasi. Menurut Leech (1993:1) seseorang tidak dapat mengerti sifat bahasa apabila tidak mengerti pragmatik, hal tersebut dikarenakan bahasa digunakan sebagai sumber komunikasi. Salah satu bidang pragmatik yang menonjol adalah tindak tutur. Pragmatik dan tindak tutur mempunyai hubungan yang erat pada bidang kajiannya. Secara garis besar antara tindak tutur dengan pragmatik membahas tentang makna tuturan yang sesuai konteksnya.

Tindak Tutur menurut Austin (1962) adalah Speech Act. Terdapat dua hal yang terkandung dalam tindak tutur yaitu Speech (ujaran) dan Act (tindakan). Teori tindak tutur awal mulanya dikemukakan oleh John Austin dan John Searle. Apabila

\footnotetext{
${ }^{*}$ Artikel Skripsi Fakultas IImu Budaya Universitas Dian Nuswantoro
} 
Oktaviani Saputri, Tuturan Melarang dalam Film Spirited Away

Austin membagi tuturan berdasarkan jenisnya menjadi tiga jenis, yaitu tuturan Lokusi, Ilokusi dan Perlokusi, maka Searle mengembangkan teori dari Austin dengan menggolongkan tindak Ilokusi menjadi lima jenis, yaitu tindak tutur asertif, direktif, ekspresif, komisif, deklaratif. Salah satu tindak Ilokusi yang akan dikaji dalam penelitian ini adalah tindak tutur direktif.

Tindak tutur direktif memiliki daya yang dituturkan penggunanya sebagai bentuk perintah, permohonan, pemberi saran, melarang dan bentuknya bisa berupa tuturan positif atau negatif. Tindak tutur direktif fungsinya untuk mempengaruhi petutur atau mitra tuturnya untuk melakukan sesuatu seperti yang diungkapkan penutur. Dalam petuturan, penutur memakai susunan kata yang sangat berlawanan maksudnya. Hal ini menimbulkan beragam tindak tutur yang dipengaruhi oleh berbagai faktor termasuk konteks dan tujuan penutur. Untuk menyatakan bahwa suatu tuturan dikatakan tindak tutur direktif dilihat dari konteks tuturan.

Tindak tutur tidak langsung dalam percakapan merupakan tuturan yang disampaikan penutur kepada lawan tutur yang tidak sesuai maksud yang diucapkannya. Dalam film Spirited Away ini banyak menggunakan tuturan melarang. Sehingga penelitian ini mengkaji tindak tutur direktif melarang, kemudian tuturan melarang dalam film tersebut akan dikategorikan sebagai tindak tutur langsung maupun tidak langsung. Serta dikaji tindak tutur melarang jika dilihat dari segi konteks dan pola melarang dalam Bahasa Jepang.

Pentingnya penelitian tindak tutur direktif melarang yaitu tergantung pada konteks situasinya, dalam hal ini tuturan tidak harus bersifat sopan. Seperti contoh "Jangan disentuh, nanti kesetrum" yang dituturkan untuk atasan atau tamu tidak selalu menggunakan tindak tutur tidak langsung. Tindak tutur melarang yaitu tuturan yang mengandung makna pragmatik imperatif larangan yang artinya penutur melarang mitra tuturnya melakukan sesuatu.

\section{METODE PENELITIAN}

\section{Ancangan Penelitian}


Penelitian ini menggunakan metode deskriptif kualitatif karena pada penelitian ini lebih menekankan pada makna dan proses dari hasil suatu aktivitas. Jadi dalam penelitian kualitatif ini bukan hanya menyajikan data apa adanya melainkan juga berusaha menginterpretasikan faktor yang berlaku meliputi sudut pandang atau proses yang sedang berlangsung.

\section{Data dan Sumber Data}

Data yang dianalisis dalam penelitian ini adalah tindak tutur yang mengandung ilokusi direktif melarang atau yang sepadan dengan makna 禁止 (kinshi 'larangan'), Sementara sumber data yang digunakan untuk bahan analisis adalah Film Spirited Away atau Sen to Chihiro no Kamikakushi.

\section{Teknik Pengumpulan Data}

1. Menonton secara keseluruhan film Spirited Away;

2. Menyimak dan mentranskrip data percakapan dari seluruh tokoh;

3. Memilah tuturan yang mengandung tindak tutur direktif melarang (terdapat 41 tuturan);

4. Mengkategorikan tindak tutur melarang berdasarkan konteksnya sesuai dengan pola bahasa Jepang dari Namatame, dan menghasilkan 16 data yang dianalisis.

\section{Teknik Analisis Data}

Setelah data terkumpul penulis melakukan tahap analisis data. Tahapan analisis data pada penelitian ini sebagai berikut :

1. Mengecek kembali data dan memastikan data tersebut merupakan tindak tutur larangan;

2. Setelah diperoleh data tersebut kemudian mengolah data untuk menentukan konteks yang muncul dalam situasi percakapan yang diuraikan berdasarkan teori SPEAKING milik Hymes; 
Oktaviani Saputri, Tuturan Melarang dalam Film Spirited Away

3. Menganalisis penggunaan tindak tutur melarang berdasarkan pola Bahasa Jepang dari Namatame;

4. Mengkategorikan ke dalam tindak tutur langsung maupun tidak langsung

\section{HASIL DAN PEMBAHASAN}

Setelah analisis dilakukan didapatkan hasil berupa pola tuturan yang termasuk melarang dalam Bahasa Jepang

1. Pola Verba ru+ na

Kutipan Data 1

Kaishain : 砂金だ！砂金だ！わあーっ！

Sakinda! sakinda!waa

'Emas! Ada emas!'

Yubaaba : こら！かいしゃのものだ！かってにとるな！

Kora! kaishamonoda! Katte ni toruna!

'Jangan diambil ! Itu milik perusahaan !'

(01:05:28 01:05:33)

Pada percakapan data 1 terdapat tuturan こら! かいしゃのものだ! かって にとるな! “Kora! kaishamonoda! Katte ni toruna!” yang memiliki arti Jangan diambil ! Itu milik perusahaan ! tuturan tersebut merupakan tuturan larangan secara langsung, akhiran na pada tuturan tersebut digunakan untuk melarang lawan tuturnya agar tidak melakukan sesuatu yang dimaksudkan oleh penutur. Biasanya pola akhiran na digunakan oleh pria, bentuk larangan ini bersifat informal kasar apabila ditujukkan kepada orang lain. Penutur menggunakan bentuk ini untuk mempertegas larangan dan menekankan otoritasnya. Daya ilokusinya adalah untuk menghentikan tindakan para pegawainya yang berebut emas yang disebarkan oleh salah satu tamunya. Dari segi bentuknya tuturan 1 termasuk modus imperatif, karena isinya larangan untuk tidak mengambil emas perusahaan. Pada tuturan かってにとるな！ 
dari とる yang artinya mengambil dan akhiran na yang mempunyai maksud larangan. Dari ciri-ciri tersebut menghasilkan tuturan melarang untuk jangan mengambil karena kerusuhan para pegawai yang berebut emas sehingga Yubaaba dengan tegas melarang menggunakan pola akhiran $\sim$ na.

Pada pola V ru na di atas digunakan dalam konteks larangan yang tegas yang dituturkan untuk menunjukkan kuatnya otoritas penutur dibandingkan dengan mitra tuturnya, terutama jika dituturkan oleh penutur perempuan. Dengan adanya pemarkah larangan yang terdapat dalam tuturan, berarti dapat diidentifikasi sebagai ilokusi direktif langsung.

2. Pola $\sim$ naide

Kutipan Data 2

Chihiro： あの、名前ってここですか?

ano, namaette koko desuka?

'Um, aku harus menulis namaku disini ?'

Yubaaba：そうだよもうぐずぐずしないでさっさとかきな

soudayou тои guzиguzu shinaide sassatokakina

'Benar! Jangan banyak bicara dan cepat lakukan!'

(00:39:38 00:39:44)

Pada penelitian tersebut menunjukkan bahwa penggunaan bentuk direktif melarang dapat dilihat dari konteks yang melatari percakapan tersebut. Chihiro adalah seorang anak yang meminta pekerjaan kepada Yubaaba, sebagai jalan untuk menyelamatkan kedua orang tuanya yang disihir Yubaaba menjadi babi.

Pada temuan tuturan data 2 そうだよもうぐずぐずしないでさっさとかきな

tuturan tersebut memiliki akhiran $\sim$ na mempunyai arti "jangan banyak bicara, cepat lakukan!”. Tuturan tersebut mempunyai daya ilokusi menghentikan tindakan mitra tutur, yakni berbicara atau bertanya terus menerus. Bentuk larangan akhiran na menurut Namatame biasanya terkesan kasar dalam penyampaian dan biasanya 
Oktaviani Saputri, Tuturan Melarang dalam Film Spirited Away

digunakan oleh laki-laki atau biasa dipakai atasan ke bawahan. Pada konteks percakapan data 2 berupa tuturan larangan bersifat kasar kemudian penutur juga menuturkan tuturan perintah untuk segera melakukan menulis nama. Pola akhiran na pada tuturan tersebut bisa dipakai untuk atasan yang ingin melarang seseorang di bawah derajatnya karena pola ini bersifat informal dan kasar. Yubaaba menuturkan tuturan larangan "jangan banyak bicara" kemudian diikuti tuturan perintah untuk cepat menuliskan namanya. Tuturan yang diucapkan oleh Yubaaba sebagai atasan kepada Chihiro sebagai bawahan diucapkan secara langsung.

3. Pola te wa ikenai

Kutipan Data 3

Chihiro : 電車だ !

densha da!

'Ada kereta!'

Haku

:ここへ来てはいけない! すぐ戻れ！

koko e kite wa ikenai! sugu modore!

'Kau tak boleh datang kemari ! Kembalilah!'

Haku

: じきによるになる. そのまえにはやくもどれ！

jikini yoruninaru sono maeni hayaku modore!

'Sekarang hampir malam ! Pergilah sebelum gelap!'

(00:11:08 00:11:26)

Pada tuturan yang diucapkan Haku adalah tuturan direktif melarang untuk jangan berada di tempat itu, kemudian menuturkan perintah untuk cepat kembali. Tuturan melarang tersebut dituturkan secara langsung agar lawan tutur yang menerima untuk tidak melakukan tindakan. Tuturan yang dituturkan Haku merupakan tindak tutur langsung karena digunakan secara imperatif dengan maksud sebagai larangan. Pada tuturan yang diucapkan Haku adalah tuturan direktif melarang untuk jangan berada di tempat itu, kemudian menuturkan perintah untuk cepat kembali. 
Tuturan melarang tersebut dituturkan secara langsung agar lawan tutur yang menerima untuk tidak melakukan tindakan. Tuturan yang dituturkan Haku merupakan tindak tutur langsung karena digunakan secara imperatif dengan maksud sebagai larangan supaya jangan berada disitu dengan intonasi yang naik.

\section{Pola janai}

Kutipan Data 4

Yubaaba

: 欲にかられてとんでもない客を引き入れたもん

だよ

yoku ni kara rete tondemonai kyaku wo hikiireta monodayo 'Ketamakanmu mengundang tamu yang merepotkan'

Yubaaba :あたしが行くまでよけいなことをすんじやないよ Atashi ga iku made yokeina koto wo sunjanai yo

'Jangan lakukan hal bodoh sampai aku ke sana'

(01:19:23 01:19:30)

Pada tuturan data ke 4 Yubaaba menuturkan tuturan あたしが行くまでよけ いなことをすんじやないよ“Atashi ga iku made yokeina koto wo sunjanai yo”yang artinya "Jangan lakukan hal bodoh sampai aku kesana" merupakan tuturan larangan dari pola bahasa Jepang janai bentuk larangan ini digunakan untuk melarang mitra tuturnya agar tidak melakukan sesuatu, atau tidak mengizinkan permintaan seseorang yang disampaikan secara langsung kepada lawan tutur. Biasanya digunakan untuk atasan kepada bawahan, kerabat terdekat, dan orang tua kepada anaknya. Seperti yang dituturkan oleh Yubaaba kepada Haku menggunakan janai melarang untuk jangan pergi dahulu sebelum dia datang dan Yubaaba menggunakan tindak tutur larangan bersifat informal yang dituturkan secara langsung kepada lawan tuturnya. 
Oktaviani Saputri, Tuturan Melarang dalam Film Spirited Away

5 Pola dame

Kutipan Data 5

Chihiro : おとうさんおかあさんきっとたすけてあげるから!市んまり 太っ ちやだめだよ、食べられちやうからね！

otousan okaasan kitto tasukete agerukara! Anmari futotcha damedayo 'Ayah, ibu, aku berjanji akan menyelamatkanmu ! Jangan jadi terlalu gemuk atau mereka akan memakanmu !'

(00:48:19 00:48:24)

Penggunaan tindak tutur direktif melarang pada data 15 terdapat pada tuturan あんまり太っちやだめだよ. Dame merupakan salah satu bentuk pola melarang imperatif yang biasa digunakan untuk semua orang dan tidak memandang informal, sopan atau derajatnya selagi itu larangan yang baik. Seperti yang dituturkan oleh Chihiro kepada orang tuanya menggunakan dame melarang untuk jangan terlalu gemuk karena bisa menjadi santapan dan Chihiro menggunakan tindak tutur larangan bersifat informal yang dituturkan secara langsung kepada lawan tuturnya. Chihiro menggunakan tindak tutur imperatif larangan untuk melarang orang tuanya agar jangan menjadi terlalu gemuk. Chihiro menuturkan larangan secara langsung kepada mitra tuturnya walaupun tidak di respon.

\section{SIMPULAN}

Dari sumber data ditemukan penggunaan bentuk tuturan ilokusi langsung melarang, yaitu: pola $\sim \mathrm{V} r u$ na, $\sim$ te wa ikenai, $\sim$ naide, $\sim$ dame, dan janai. Bentuk ilokusi langsung digunakan oleh orang yang punya otoritas yang kuat terhadap mitra tuturnya. Dengan otoritasnya penutur tidak perlu menggunakan tuturan tak langsung yang biasanya menekankan pada kesopanan. 


\section{DAFTAR PUSTAKA}

Austin, J. (1962). How to Do Things With Word. London: Oxford University Press.

Chino, N. (2008). Partikel Penting Bahasa Jepang. Jakarta: Kesiant Blanc.

Dwi Cahyani, S. W. (2015). Analisis Tindak Tutur Ilokusi dalam Bahasa Jepang. Skripsi FBS Universitas Semarang: tidak diterbitkan.

Hymes, D. (1972). Foundations of Sociolinguistics: An Ethnographic Approach. Philadelphia: University of Pennsylvania Press.

Khair, U. (n.d.). Retrieved Oktober 19, 2017, fromwww.academia.edu/ 4728139/PRAGMATIK_Tindak_Tutur_II.

Leech, G. (1993). Prinsip-prinsip Pragmatik. Jakarta: Universitas Indonesia.

Namatame, Y. (1996). Nihongo Kyoushi no Tame no Gendai Nihongo Hyougen Bunten. Jepang: Kabushiki Kaisha Honjisha.

Nugrahanti Rahayu, N. P. (2016). Bentuk dan Jenis Tindak Tutur Direktif. Skripsi FBS Universitas Negeri Yogyakarta: tidak diterbitkan.

Saifudin, A. (2005). Faktor Sosial Budaya dan Kesopanan Orang Jepang dalam Pengungkapan Tindak Tutur Terima Kasih pada Skenario Drama Televisi Beautiful Life Karya Kitagawa Eriko. Tesis. Pascasarjana UI.

Saifudin, A. (2010). Analisis Pragmatik Variasi Kesantunan Tindak Tutur Terima Kasih Bahasa Jepang Dalam Film Beautiful Life Karya Kitagawa Eriko. LITE 6(2), 172-181.

Saifudin, A. (2018). Konteks dalam Studi Linguistik Pragmatik. Lite 14 (2). 108-117.

Sari, D. N. (2013). Tindak Tutur Tidak Langsung Literal. www.journal.unair.ac.id, download-fullpapers-japanology5761d54fa62full.pdf.diunduh pada tanggal 5 November 2017

Wijana, I. (1996). Dasar-dasar Pragmatik. Yogyakarta: Penerbit Andi.

Wijana, I. (2011). Analisis Wacana Pragmatik: Kajian Teori dan Analisis. Surakarta: Yuma Pustaka.

Yule, G. (1996). Pragmatics. New York: Oxford University Press.

Yule, G. (2006). Pragmatik. Yogyakarta: Pustaka Pelajar. 